ROCZNIKI HISTORYCZNE

Rocznik LXXXIII — 2017

TOMASZ ZAWADZKI (Uniwersytet Śląski, Katowice)

\title{
Mieszczanie, rycerze, burgrabiowie Kariera śląskiej rodziny von Reussendorf w czasach przedhusyckich
}

Zarys treści: Artykuł poświęcony jest śląskiej rodzinie Reussendorfów od końca XIII do początku XV w. Była to rodzina mieszczańska wywodząca się z Lwówka, która weszła do stanu rycerskiego, a za sprawą służby dla książąt awansowała do elity majątkowej w księstwie świdnicko-jaworskim. Artykuł przedstawia genealogię, rozwój majątku oraz pozycję społeczną rodziny.

Content outline: The paper is devoted to the Silesian family of the Reussendorfs from the end of the $13^{\text {th }}$ century to the beginning of the $15^{\text {th }}$ century. It was a burgher family from Lwówek (Löwenberg), which entered the knighthood estate, and thanks to their service at the ducal courts, achieved a high position among the elite of the Duchy of Świdnica-Jawor (Schweidnitz-Jauer). The paper presents the genealogy, estate expansion, and social position of the family.

Słowa kluczowe: Reussendorf, księstwo świdnicko-jaworskie, Lwówek, awans mieszczan, rycerstwo śląskie, burgrabiowie na Śląsku

Keywords: Reussendorfs, Duchy of Świdnica-Jawor (Schweidnitz-Jauer), Lwówek (Löwenberg), advancement of burghers, Silesian knighthood, burggraves in Silesia

Jednym z charakterystycznych zjawisk w procesie kształtowania się śląskiego rycerstwa i szlachty w średniowieczu było przenikanie w ich szeregi przedstawicieli stanu mieszczańskiego. Zamożni mieszkańcy miast w drugiej połowie XIII w. zaczęli się interesować dobrami ziemskimi, a nabywszy je, zgodnie z prawem lennym stawali się zobowiązani do konnej służby wojskowej. Zrównywali się zatem w swych prawach i obowiązkach z rycerstwem. Z czasem część z nich zaczęła żyć na sposób rycerski, przyjmowała atrybuty tego stanu i porzuciła swoją dotychczasową kondycję. Przodowali pod tym względem mieszczanie wrocławscy, niemniej podobne zjawiska widoczne były również w mniejszych śląskich miastach ${ }^{1}$. Niniejszy artykuł poświęcony jest pochodzącej z Lwówka rodzinie Reussendorfów, która stanowi dobry przykład awansu społecznego mieszczaństwa.

1 M. C e t w iń s k i, Rycerstwo śląskie do końca XIII w., cz. I: Pochodzenie - gospodarka - polityka, Wrocław 1980, s. 128-130; T. J u r e k, Vom Rittertum zum Adel. Zur Herausbildung des Adelsstandes im mittelalterlichen Schlesien, w: Adel in Schlesien, t. I: Herrschaft - Kultur - Selbstdarstellung, München 2010, s. 67; t e n ż e, Najdawniejsze wywody szlachectwa na Śląsku, Śląski Kwartalnik Historyczny Sobótka 49, 1994, s. 200. 
Na temat Reussendorfów powstało do tej pory sporo publikacji. Krótki zarys dziejów rodziny dał już w XVIII w. znany badacz genealogii szlachty śląskiej Johann Sinapius $^{2}$. Nazwisko Reussendorfów wielokrotnie pojawia się w dawniejszych pracach o dziejach Lwówka - od kroniki Benjamina Sutoriusa (1784) po historię miasta Paula Klebera (1914) ${ }^{3}$. Najwięcej uwagi poświęcił interesującej nas rodzinie dziewiętnastowieczny historyk Ewald Wernicke, który dał jej wywód genealogiczny ${ }^{4}$. O aktywności na sąsiednich Łużycach pisali Hermann Knothe oraz Walter Boetticher $^{5}$. Z nowszej literatury wymienić trzeba artykuły Dagmary Adamskiej-Heś oraz Jarosława Granicznego ${ }^{6}$. Nikt jednak nie przedstawił dotąd całościowego ujęcia dziejów Reussendorfów, a zebrane informacje można jeszcze także w wielu miejscach uzupełnić i uściślić, zarówno jeśli chodzi o genealogię, stan majątkowy rodziny, jak i określenie społecznej pozycji poszczególnych jej przedstawicieli. Celem niniejszego artykułu jest więc podsumowanie dotychczasowego stanu badań oraz jego poszerzenie na podstawie całego dostępnego dziś materiału źródłowego ${ }^{7}$. Rozważania obejmują okres od końca XIII do pierwszych dziesięcioleci XV w., na który przypadła aktywność czterech pierwszych uchwytnych źródłowo pokoleń rodziny.

Miejscowością, z której pisali się Reussendorfowie, był najprawdopodobniej dzisiejszy Raszów (przed 1945 r. Reussendorf) pod Kamienną Górą - wzmiankowany na początku XIV w. w księdze uposażeń biskupstwa wrocławskiego jako Rysindorf ${ }^{8}$.

2 J. S i n a p i u s, Schlesische Curiositäten, t. I, Leipzig 1720, s. 748-750, t. II, LeipzigBreslau 1728, s. 907.

3 B. G. S u torius, Die Geschichte von Löwenberg aus Urkunden und Handschriften gesammelt, t. I, Bunzlau 1784; P. K 1 e b e r, Löwenberg unter den Piasten, t. I, Löwenberg 1914.

4 E. We r n i c k e, Chronik der Stadt Bunzlau von den ältesten Zeiten bis zur Gegenwart, Bunzlau 1884; t e n ż e, Urkundliche Beiträge zur Geschichte der Adelsfamilien in den ehemals vereinigten Kreisen Bunzlau-Löwenberg, Vierteljahrsschrift für Heraldik, Sphragistik und Genealogie 14, 1886, s. 484-490.

${ }_{5} \mathrm{H}$. K n o th e, Geschichte des oberlausitzer Adels und seiner Güter vom XIII. bis gegen Ende des XVI. Jahrhunderts, Leipzig 1879, s. 441-442; t e n że, Die Besitzungen des Bisthums Meißen in der Oberlausitz, Archiv für die sächsische Geschichte 6, 1867, s. 193-194; W. B o e t t i c h e r, Der Adel des Görlitzer Weichbildes um die Wende des 14. und 15. Jahrhunderts, Görlitz 1927, s. 178-179.

6 D. A d a m s k a - H eś, Burgrabiowie księstwa świdnicko-jaworskiego w drugiej połowie XIV w., Śląski Kwartalnik Historyczny Sobótka 56, 2001, s. 213-223; J. G r a n i c z n y, Rycerstwo księstw jaworskiego i świdnickiego w latach 1274-1346, w: Człowiek i środowisko w Sudetach, Wrocław 2000, s. 169-209.

7 Bazę źródłową wykorzystaną podczas pisania niniejszego artykułu stanowiły przede wszystkim publikowane zbiory dokumentów: Regesten zur schlesischen Geschichte, wyd. C. Grünhagen, K. Wutke, E. Randt, Codex diplomaticus Silesiae, t. VII, XVI, XVIII, XXII, XXIX, XXX, Breslau 1886-1930 (dalej cyt.: RS); Regesty śląskie, red. W. Korta, t. I-V, Wrocław 1975-1992 (dalej cyt.: Rśl); Landbuch księstw świdnickiego i jaworskiego, t. I-III, wyd. T. Jurek, Poznań 2000-2007 (dalej cyt.: Lb.); Urkunden der Stadt Löwenberg, wyd. H. Wesemann, cz. 1, Jahresbericht über das Realprogymnasium zu Löwenberg in Schlesien 15, 1885, s. 3-42; cz. 2, tamże 17, 1887, s. 3-32 (dalej cyt.: Wesemann); Regesten zur Geschichte der Stadt Löwenberg in Schlesien, wyd. P. Kleber, J. Ennen, cz. 1, Jahresbericht über das Realgymnasium zu Löwenberg in Schlesien 22, 1912 (dalej cyt.: Kleber-Ennen). Ważne uzupełnienia przyniosła kwerenda w wybranych zespołach Archiwum Państwowego we Wrocławiu.

${ }_{8}^{8}$ Liber fundationis episcopatus Vratislaviensis, wyd. H. Markgraf, J. W. Schulte, Codex diplomaticus Silesiae, t. XIV, Breslau 1889, s. 139. 
Poza samym nazwiskiem nie sposób jednak wskazać na związki naszej rodziny z tą miejscowością. Trudno stwierdzić, czy Reussendorfowie byli rycerskimi dziedzicami czy tylko chłopami z tej wsi. Pierwszym uchwytnym źródłowo przedstawicielem Reussendorfów był mieszczanin lwówecki o imieniu Henryk ${ }^{9}$. Lwówek (Löwenberg) należał do największych i najlepiej rozwijających się miast w księstwie świdnicko-jaworskim; bogacił się dzięki wydobyciu złota, produkcji sukna oraz korzystnemu położeniu na ważnym szlaku handlowym prowadzącym z Wrocławia na Łużyce (Hohe Straße), przez krótki okres (1281-1286) pełnił funkcję stolicy niewielkiego księstwa rządzonego przez najmłodszego syna Bolesława Rogatki - Bernarda Zwinnego. Po śmierci tego ostatniego władzę nad miastem objął jego brat Bolko I Surowy, protoplasta świdnicko-jaworskiej linii Piastów ${ }^{10}$. Lwówek stanowił jedną z głównych rezydencji Bolka, który tytułował się zrazu księciem lwóweckim, dopóki nie przyjął (od 1293 r.) tytulatury pana na zamku Książ (Fürstenberg). Wśród mieszczan lwóweckich najczęstszym beneficjentem przejawów łaski książęcej był właśnie Henryk Reussendorf ${ }^{11}$. W 1287 r. książę w uznaniu zasług Henryka Reussendorfa, określonego jako civis noster dilectus et fidelis, zwolnił od wszystkich ciężarów i powinności nadane mu wcześniej 6 łanów w podlwóweckich Rakowicach (Gross-Rackwitz), osobnym zaś dokumentem uwolnił należący do niego oraz pewnego Hogera i jego braci folwark w Dworku (Höfel), położonym kilka kilometrów na wschód od Lwówka. W 1293 r. książę, znów powołując się na wierne służby Henryka, nadał mu inny folwark pod Lwówkiem, należący wcześniej do Kunemana Seidlitza, za co obdarowany dawać miał co roku 2 pary butów reńskich ${ }^{12}$. Henryk wybił się niewątpliwie dzięki przychylności księcia, który - jak się powszechnie przyjmuje w ogóle sprzyjał miastom ${ }^{13}$. Zgromadzony przez niego majątek ułatwił z pewnością karierę jego potomkom. O ambicji Henryka świadczy zadbanie o wykształcenie co najmniej jednego z synów, który zrobił karierę duchowną.

Synami Henryka Reussendorfa byli z pewnością bracia Zygfryd, Mikołaj oraz $J^{14}{ }^{14}$, którzy dziedziczyli po nim dobra. Cała trójka odnotowana została w źródłach po raz pierwszy w czerwcu 1322 r. Książę jaworski Henryk (syn Bolka) nadał im wówczas wieś Benotendorf pod Lwówkiem oraz sześć łanów w Rakowicach Wielkich - niewątpliwie te same, które posiadał wcześniej Henryk Reussendorf ${ }^{15}$. Ponadto w 1327 r. Zygfryd i Mikołaj uzyskali od księcia Henryka potwierdzenie przywilejów

9 E. We r n i c k e, Urkundliche Beiträge, s. 484; t e n ż e, Chronik, s. 90.

10 J. N o w a k o w a, Rozmieszczenie komór celnych i przebieg dróg handlowych na Śląsku do końca XIV w., Wrocław 1951, s. 82-84; R. G r o d e c k i, Dzieje polityczne Śląska do roku 1290, w: Historia Śląska od najdawniejszych czasów do roku 1400, t. I, Kraków 1933, s. 287.

${ }_{11}$ M. K o k o c i ń s k a, Kancelaria Bolka I księcia jaworsko-świdnickiego, Szkice Legnickie 21, 2000, s. 23-24.

12 Schlesisches Urkundenbuch, t. V, wyd. W. Irgang, Köln-Weimar-Wien 1993, nr 360, 365; t. VI, wyd. W. Irgang, Köln-Weimar-Wien 1998, nr 86. Zob. E. We r n i c k e, Urkundliche Beiträge, s. 484; P. K l e b e r, Löwenberg, s. 39-40; J. G r a n i c z n y, Rycerstwo, s. 173.

13 P. K l e b e r, Löwenberg, s. 39; K. M a l e c z y ń s k i, Śląsk w okresie od poł. XIII w. do poł. XIV w., w: Historia Śląska, t. I, cz. 1, Wrocław 1960, s. 532; J. G r a n i c z n y, Rycerstwo, s. 176; M. K o k o c iń s k a, Kancelaria, s. 24.

14 E. We r n i c k e, Urkundliche Beiträge, s. 484; J. G r a n i c z n y, Rycerstwo, s. 173.

15 RS nr 4219. Benotendorf to osada zaginiona, która zdaniem P. K l e b e r a, Löwenberg, s. 42, mogła leżeć w okolicach wsi Płóczki. 
dla swoich dóbr w podlwóweckich Płakowicach (Plakwitz). Dobra te - folwark, pastwiska nad Bobrem, a także prawo rybołówstwa i wydobycia złota w kopalni pod Sobotą - określone zostały jako należące niegdyś do Kunemana Seidlitza ${ }^{16}$. Były to zatem ten sam majątek, który otrzymał kiedyś Henryk Reussendorf.

Synowie Henryka nie byli już - w przeciwieństwie do ich ojca - nazywani mieszczanami. Największą karierę zrobił Zygfryd, który od 1327 r. w roli świadka dokumentów Henryka I jaworskiego, od połowy lat trzydziestych aż do śmierci księcia (1346) należał do ścisłego grona jego najbliższych współpracowników ${ }^{17}$. Piastował prestiżowy i przynoszący z pewnością spore dochody urząd sędziego dworskiego w Lwówku, na którym poświadczony był w 1. 1341-1346 ${ }^{18}$. Lwówek za rządów Henryka jaworskiego wciąż odgrywał znaczną rolę, jako że był największym miastem niedużego księstwa. Książę obdarowywał go przywilejami ${ }^{19}$, licząc za to na wsparcie finansowe ${ }^{20}$. Ludzie związani z Lwówkiem stanowili ważną część otoczenia Henryka. Obok Reussendorfów duże znaczenie osiągnęła zwłaszcza rodzina Renkerów, dziedzicznych wójtów tego miasta ${ }^{21}$. Działalność Zygfryda Reussendorfa wykraczała jednak poza granice księstwa jaworskiego. W 1339 r. kilkakrotnie pojawiał się w otoczeniu księcia Bolesława III legnickiego, od którego w listopadzie tego roku nabył, wspólnie ze swoim bratem Mikołajem, las zwany Hainwalde w dystrykcie złotoryjskim, ale położony niedaleko Lwówka ${ }^{22}$. Wielu ludzi z otoczenia Henryka jaworskiego posiadało majątki w księstwie legnickim i bliskie kontakty z tamtejszym dworem ${ }^{23}$.

16 RS nr 4710.

17 RS nr 4698, 4701, 5305, 5826, 6020, 6166, 6422, 6429, 6501, 6510 a, 6588, 6613, 6854, 6948, 6949, 6964; Rśl I, nr 181, 182, 243, 264, 412, 438; Lb. III, nr 761.

18 RS nr 6638, 6667; Rśl I, nr 438; W. I r g a n g, Das spätmittelalterliche Stadtbuch von Löwenberg in Schlesien, Zeitschrift für Ostforschung 45, 1996, s. 332. Możliwe jednak, że Zygfryd był sędzią dworskim w Lwówku już znacznie wcześniej, nawet w połowie lat trzydziestych (od kiedy zaczyna często występować w dokumentach książęcych). W 1335 r. wpisany został na pierwszym miejscu w testacji dokumentu wydanego przez burmistrza i rajców Lwówka (RS nr 5470) - bez urzędu, jednak przed wójtem tego miasta oraz wspomnianymi wystawcami. Zaszczytne miejsce zawdzięczać musiał wysokiej pozycji i być może już wówczas sprawowaniu urzędu sędziego dworskiego w mieście. Nieco wcześniej zmarł poprzedni sędzia Zygfryd Renker, poświadczony od 1316 do lutego 1333 r. (RS nr 3594, 4551, 4869, 4878, 5196).

19 RS nr 3700, 3906, 4259, 4698, 4700, 4701; zob. K. M a l e c z yń s k i, Śląsk, s. 536.

20 RS nr 6664; Rśl I, nr 200.

21 Renker wójt oraz sędzia dworski w Lwówku wspólnie ze swoim bratem Rudolfem w 1316 r. wymieniony został wśród familiares Henryka I (RS nr 3577). Zygfryd Renker, następca Renkera na obu urzędach i najpewniej jego syn, należał do najbliższych doradców księcia jaworskiego w 1. 1316-1333 (RS nr 3594, 4239, 4259, 4469, 4551, 4878, 5196). Był jednym z przedstawicieli księcia w rozmowach z mieszczanami Zgorzelca w sprawie złożenia przez nich hołdu w 1322 r. (RS nr 4231; H. K n o th e, Die Huldigung des Görlitzer Rathes an Herzog Heinrich von Jauer 1322, Zeitschrift des Vereins für Geschichte und Alterthum Schlesiens 8, 1868, s. 465-469).

22 RS nr 6200, 6205, 6360.

23 Za przykład posłużyć może piszący się z Nielestna (Waltersdorf) w księstwie jaworskim Albrecht Bawar, który był bardzo blisko związany zarówno z Henrykiem I, jak i Bolesławem III, a dobra miał w obu księstwach (RS nr 3383, 3399, 3435, 3484, 3645a, 3377, 3379, 3917, 3246, 6239). 
W 1342 r. Zygfryd i Mikołaj wraz z Henrykiem Frohburgiem wzięli w zastaw od księcia Jelenią Górę z dystryktem ${ }^{24}$.

Zygfryd utrzymał swą wysoką pozycję także po bezpotomnej śmierci Henryka I w 1346 r. i objęciu rządów w Jaworze przez jego bratanka, księcia Bolka II świdnickiego. Liczne dokumenty dowodzą częstej przy nim obecności Reussendorfa do 1356 r. ${ }^{25}$ Zygfryd powiększał też stale swój majątek. W maju 1354 r. wraz z synami Wincentym i Zygfrydem kupił od Bolka II lenno zamkowe Gryf (Greiffenstein) niedaleko Gryfowa Śląskiego ${ }^{26}$. Wraz z nimi nabył też dwa lata później 5 grzywien czynszu z mennicy lwóweckiej ${ }^{27}$.

Postacią o dużo mniejszym znaczeniu wydaje się brat Zygfryda, Mikołaj Reussendorf. Oprócz wspomnianych wyżej wspólnych transakcji braci, znamy jego rzadkie wystąpienia (zawsze wraz z bratem) przy księciu Henryku. Pozostawał niezbyt widoczny także w czasach po objęciu rządów w Jaworze przez Bolka II ${ }^{28}$. Ostatnia informacja pozwalająca śledzić losy zarówno Zygfryda, jak i Mikołaja pochodzi z maja 1357 r. Zadłużony książę Wacław I (syn Bolesława III), zastawił na 6 lat za 6000 grzywien obu Reussendorfom, a także licznemu gronu innych osób - m.in. biskupom Wrocławia i Lubusza oraz staroście wrocławskiemu - Złotoryję z całym dystryktem oraz Chocianów ${ }^{29}$.

Jan, trzeci z braci, obrał karierę duchowną. Od 1346 r. występował jako kanonik wrocławskiej kolegiaty św. Krzyża ${ }^{30}$. Kapitułę tę łączyły silne związki z elitą księstwa świdnicko-jaworskiego (książęta mieli wszak patronat nad szeregiem prebend). W tym samym czasie zasiadali w niej przedstawiciele liczących się w Jaworze i Świdnicy rodzin rycerskich ${ }^{31}$. W 1. 1346-1351 Jan Reussendorf zapisał kapitule 2 grzywny

24 RS nr 6988.

25 Rśl I, nr 463, 464, 465, 488, 651, 652, 655, 660, II, nr 11, 12, 13, 68, 109, 238, 1016, 1085; Wesemann I, nr 17, 18.

26 Rśl II, nr 1039.

27 Kleber-Ennen nr 54; suma ta była potem wypłacana Zygfrydowi przez radę miasta (W. I rg a n g, Das spätmittelalterliche Stadtbuch, s. 346).

${ }_{28}$ RS nr 6166, 6422, 6510 a, 6948; Rśl I, nr 182; Lb. III, nr 761; przy Bolku pojawił się zaledwie raz, w maju 1349 r. (Rśl II, nr 68).

29 Schlesiens Bergbau und Hüttenwesen. Urkunden (1136-1528), wyd. K. Wutke, Codex diplomaticus Silesiae, t. XX, Breslau 1900, s. 48-51; zob. K. R. P r o k o p, Miasta księstwa legnickiego w polityce ekonomicznej książąt Bolesława III i Wacława I (1306-1364), cz. 2, Szkice Legnickie 26, 2005, s. 23. W otoczeniu Wacława I widać Zygfryda także w 1349 i 1352 r. (Rśl II, nr 142, 599).

30 Kleber-Ennen nr 39.

31 Kanonikiem był Piotr Zedlitz, wieloletni protonotariusz Bolka II i księżnej Agnieszki, zapewne syn Kunemana burgrabiego wleńskiego i marszałka Henryka jaworskiego (C. K u c he n d o r f, Das Breslauer Kreuzstift in seiner persönlichen Zusammensetzung von der Gründung (1288) bis 1456, Breslau 1937, s. 148; D. A d a m s k a - Héś, Personel kancelaryjny księżnej Agnieszki świdnicko-jaworskiej w latach 1368-1392, Śląski Kwartalnik Historyczny Sobótka 55, 2000, s. 435; T. Z a w a d z k i, Rodzina von Zedlitz w księstwach świdnicko-jaworskim oraz legnickim w XIV wieku, Średniowiecze Polskie i Powszechne 9 (13), 2017, [w druku]), a także Jan Hoberg, syn Kiczolda, blisko związanego z Henrykiem jaworskim i sędziego dworskiego w Świdnicy (C. K u c h e n d o r f, Das Breslauer Kreuzstift, s. 102; RS nr 3253, 5305; Rśl I, nr 750). 
rocznie z Benotendorf i Płóczek (Görisseiffen) ${ }^{32}$, a w grudniu 1361 r. nabył od braci Ebersbach 2 grzywny czynszu z Krzywej (Kreibau) pod Chojnowem ${ }^{33}$, pod władzą księcia Ludwika brzeskiego (syna Bolesława III). Jan Reussendorf uwzględniony został w testamencie księcia Ludwika z 1360 r.: władca zapisał mu auream lineam ante altare (sznur?) ${ }^{34}$. Jan był potem kanonikiem legnickiej kolegiaty św. Grobu (1363-1372), zapewne za sprawą księcia Ludwika, który sprawował w Legnicy rządy opiekuńcze. Jan po raz ostatni występuje w dokumencie dotyczącym kupna mszału od wikariuszy kolegiaty świętokrzyskiej ${ }^{35}$.

Synami Zygfryda Reussendorfa byli, wspomniani już przy okazji wspólnie z ojcem zawartych transakcji z 1354 i 1356 r., Wincenty i Zygfryd. Ich siostrą była Jadwiga, odnotowana w 1356 r. jako zakonnica klasztoru w Lubomierzu ${ }^{36}$. Wincenty należał, obok ojca i stryja, do spółki, która w 1357 r. brała w zastaw Złotoryję i Chocianów. W odnośnym dokumencie nazwany został panem (,herr”) i zaliczony do rycerzy pasowanych ${ }^{37}$. Był pierwszym przedstawicielem rodziny, który dostąpił pasowania $^{38}$. Nieco później pasem pochwalić mógł się także jego młodszy brat Zygfryd $^{39}$. W przywileju cesarza Karola IV dla stanów księstwa świdnicko-jaworskiego z 1369 r. Wincenty wymieniony został jako burgrabia zamku Gryf (dzierżył go po ojcu), Zygfryd zaś - jako burgrabia we Lwówku ${ }^{40}$. Wincenty występował też jako

32 Kleber-Ennen nr 39, 47.

33 R. Rö s s le r, Urkunden Herzog Ludwig I. von Brieg, cz. 1, Zeitschrift des Vereins für Geschichte und Alterthum Schlesiens 6, 1884, s. 1-96, tu nr 377. Do 1358 r. Jan posiadał też altarię w kolegiacie świętokrzyskiej (C. Ku c h e n d orf, Das Breslauer Kreuzstift, s. 118).

${ }^{34}$ Urkunden der Stadt Brieg, wyd. C. Grünhagen, Codex diplomaticus Silesiae, t. IX, Breslau 1870, s. 246-247; zob. A. K a r ł o w s k a - K a m z o w a, Fundacje artystyczne księcia Ludwika I brzeskiego, Opole-Wrocław 1970, s. 47-51; F. S z a fr a ń s k i, Ludwik II brzesko-legnicki. Feudał śląski z doby późnego średniowiecza, Wrocław 1972, s. 84-85; testament nie wszedł w życie, Ludwik żył potem jeszcze 38 lat, a przed śmiercią sporządził (1396) nowy testament (Urkunden der Stadt Brieg, s. 253-255).

35 Urkundenbuch der Stadt Liegnitz und ihres Weichbildes bis zum Jahre 1455, wyd. F.W. Schirrmacher, Liegnitz 1866, nr 236; Wrocław, Archiwum Państwowe, rep. 132a, depozyt parafii w Lwówku, nr 8, 9; Kleber-Ennen nr 80. Zob. S. J u j e c z k a, Duchowni średniowiecznej Legnicy. Studium prozopograficzne nad klerem diecezjalnym, Legnica 2006, s. 308 ,

36 Pobierane było przez nią z lwóweckiego ratusza 5 grzywien rocznie z dochodów menniczych w Lwówku, które należały wcześniej do Zygfryda, Lb. III, nr 1904; B. G. S u t o r i u s, Die Geschichte, s. 64-65; D. A d a m s k a, Fundacje dewocyjne rycerstwa księstwa świdnicko-jaworskiego w średniowieczu, Poznań-Wrocław 2005, s. 113.

37 Schlesiens Bergbau, s. 48-51 = Rśl III, nr 492.

38 Tytuł ,herr” oznaczał wówczas osobę pasowaną na rycerza (A. B o g u c ki, Termin miles w regestach śląskich XIII i XIV, w: Społeczeństwo Polski średniowiecznej, t. I, Warszawa 1981, s. 225; t e n ż e, Nazwy rycerstwa w Regestach śląskich, Śląski Kwartalnik Historyczny Sobótka 46, 1991, s. 21).

39 Jako rycerz pasowany występował od $1366 \mathrm{r}$. w zachowanych od tego roku zapiskach świdnicko-jaworskiego landbucha (Lb. I, nr 724 n.).

40 Lehns- und Besitzurkunden Schlesiens und seiner einzelnen Fürstenthümer im Mittelalter, wyd. C. Grünhagen, H. Markgraf, t. I, Leipzig 1881, s. 512. Niedługo później Gryf znajdował się już w innych rękach, w 1372 r. burgrabią był tam Frycze von Rohnau 
landwójt w Złotoryi - zastawionej Bolkowi świdnickiemu przez Wacława legnickiego. W styczniu 1368 r. landwójtostwo odsprzedał Albrechtowi Zedlitzowi oraz Jesse Pförtner ${ }^{41}$. Zygfryd natomiast obok lenna zamkowego we Lwówku posiadał także tamtejsze landwójtostwo ${ }^{42}$. W odróżnieniu od ojca, bracia nie byli już blisko związani w dworem książęcym ${ }^{43}$. Osiągnąwszy bogactwo i znaczenie, Reussendorfowie skupiali się głównie na własnej działalności gospodarczej w zachodniej części księstwa świdnicko-jaworskiego, gdzie wokół należących do nich zamków koncentrowały się ich dobra. Aktywność publiczną zwiększyli dopiero po śmierci księcia. Zwłaszcza Zygfryd pod koniec życia, w drugiej połowie lat osiemdziesiątych, zaczął stosunkowo często pojawiać się przy wdowie po Bolku II, księżnej Agnieszce, która zachowała dożywotnie rządy (do 1392 r.) ${ }^{44}$. Choć Reussendorfowie nie należeli do pierwszoplanowych postaci w jej otoczeniu, za wyświadczone usługi Wincenty został wynagrodzony przez Agnieszkę w 1385 r. lennem zamkowym w Fünfhausen, zamku leżącym najprawdopodobniej opodal Gryfowa Śląskiego ${ }^{45}$. W tych właśnie stronach zlokalizowany był majątek Reussendorfów. Wincenty posiadał dobra w Płakowicach, Rakowicach Wielkich, a także w Olszynie (Langenöls) i Proszówce (Neudorf) $^{46}$, Zygfryd zaś - w Płóczkach, Skorzynicach (Hartliebsdorf), Zbylutowie (Teutschmansdorf), Gaszowie (Gödwinsdorf), także w Olszynie i Rakowicach Wielkich i Małych ${ }^{47}$. O pozycji społecznej braci świadczyły, obok tych majątków, w tym

(E. Wernicke, Urkundliche Beiträge, s. 509; T. Jurek, Obce rycerstwo na Śląsku do połowy XIV wieku, Poznań 1996, s. 277); informacja ta zaczerpnięta została z pracy J. G. B e r g m a n n a, Beschreibung und Geschichte der alten Burgfeste Greiffenstein, Bunzlau 1832, s. 49, którego źródłem miały być „Original Briefen der Herzogin Agnes”. Pewne prawa do lenna zamkowego w Lwówku posiadał najpewniej także Wincenty. Krótko bowiem po jego śmierci (1388) jego synowie przekazali swojemu stryjowi wspólnie - zatem prawdopodobnie odziedziczone - 60 grzywien czynszu z tego lenna (Lb. II, nr 604), o czym niżej.

${ }^{41}$ Lb. I, nr 219; jest to jedyna informacja o piastowaniu tej funkcji przez Wincentego.

42 Podobnie jak w przypadku brata, nie wiadomo, kiedy Zygfryd objął urząd landwójta. W 1389 r., tuż przed śmiercią, prawa do niego przekazał swoim córkom (Lb. II, nr 608), o czym niżej.

43 Wśród licznych zapisek landbucha $\mathrm{z}$ dwóch ostatnich lat panowania Bolka II odnotowani zostali u jego boku zaledwie kilka razy (Lb. I, nr 65, 96, 147, 181, 210, 212, 244).

44 Wincenty świadkował łącznie w kilkunastu dokumentach księżnej, Zygfryd zaś w ponad dwudziestu, z czego większość pochodzi z 1. 1385-1388 (Lb. I-II, wg indeksu); wystawiane były przeważnie w Świdnicy, gdzie księżna spędzała większość czasu (T. J u r e k, In sede viduali. Nad itinerarium księżnej świdnickiej Agnieszki z lat 1385-1392, w: Europa Środkowa i Wschodnia w polityce Piastów, Toruń 1997, s. 284).

${ }^{45}$ Lb. II, nr 102. Zdaniem D. A d a m sk i ej-H e ś, Burgrabiowie, s. 216, zamek ten znajdował się na Dolnych Łużycach. Prawdopodobnie jednak zlokalizowany był na Śląsku. W dystrykcie gryfowskim widział go T. J u rek (Lb. II, s. 298). W. Were s z c zyń s ki, Fünfhausen - zaginione lenno zamkowe u podnóża Gór Izerskich, Rocznik Jeleniogórski 36, 2004, s. 51-74, lokalizuje go w Rębiszowie na wzniesieniu Urwista, kilkanaście kilometrów od Gryfowa, a A. B o g u s z e w i c z, Corona Silesiae. Zamki Piastów fürstenberskich na południowym pograniczu księstwa jaworskiego, świdnickiego i ziębickiego do połowy XIV wieku. Wrocław 2010, s. 163-164, identyfikuje z zamkiem Podskale w Rząsinach, między Gryfowem a Lwówkiem.

${ }^{46}$ Lb. I, nr 178, 256, 551, II, nr 134, 1100.

${ }^{47}$ Lb. I, nr 90, 243, 724, 551, 558, 559, 724, II, nr 99, 343, 527, 604, 605. 
zamków, będących wyróżnikiem najwyższego statusu ${ }^{48}$ - także zawierane małżeństwa. Żony Wincentego i Zygfryda wywodziły się ze znanych rodzin rycerskich. Żona Wincentego, Anna, była najpewniej córką Konrada Falkenhaina, wieloletniego starosty wrocławskiego (1339-1361) i jednej z najbardziej wpływowych wówczas postaci na Śląsku ${ }^{49}$. Żoną Zygfryda została natomiast Eneda, córka Dytryka Predla i Enedy ${ }^{50}$. Predlowie wywodzili się z Turyngii, a do księstwa świdnicko-jaworskiego przybyli pod koniec XIII w. Dytryk miał dobra pod Jaworem i pisał się z pobliskiego Luboradza (Lobris), gdzie stał należący do niego dwór ${ }^{51}$. Wincenty po raz ostatni wystąpił w dokumencie wystawionym w Świdnicy 9 XI 1385, jako zmarły zaś wymieniony został 27 IX 1388 r. $^{52}$ Zygfryd natomiast zmarł między 4 II 1389 a 29 VI 1390 r. $^{53}$

Do tego samego pokolenia co Wincenty i Zygfryd należał Mikołaj Reussendorf, o którego pochodzeniu brak pewnych informacji. Prawdopodobnie był ich bratem stryjecznym, a więc synem Mikołaja. Mikołaj młodszy znany jest z niewielu dokumentów z lat 1367-137454. Jego żoną była Agnieszka, której w 1374 r. zapisał dobra w Rakowicach (Ekhardsdorf) oraz Zapuście (Vogelsdorf) ${ }^{55}$, córką natomiast Gertruda, w 1367 r. poświadczona jako żona Fryczka z wywodzącej się z Miśni, a osiadłej na Śląsku od końca XIII w. rodziny von Waldau ${ }^{56}$. Jej przedstawiciele odgrywali sporą rolę w księstwie świdnicko-jaworskim: Henryk Waldau, zapewne ojciec Fryczka, często występował u boku Henryka jaworskiego ${ }^{57}$, braćmi Fryczka byli zaś najpewniej Henczel burgrabia bolesławiecki i Bernard protonotariusz księcia Henryka ${ }^{58}$.

${ }^{48}$ T. J u r e k, Elity Śląska w późnym średniowieczu, w: Kolory i struktury średniowiecza, Warszawa 2004, s. 415.

${ }_{49}$ W 1366 lub 1367 r. Wincenty zapisał Annie folwark w Płakowicach (Lb. I, nr 178); jednym z opiekunów oprawy został jej brat Ulryk Falkenhain, najpewniej tożsamy z synem starosty Konrada (T. J u r e k, Obce rycerstwo, 219). O Konradzie: E. W ó ł k i e w i c z, Capitaneus Slesie. Królewscy namiestnicy księstwa wrocławskiego i Śląska w XIV i XV wieku, w: Monarchia w średniowieczu - władza nad ludźmi, władza nad terytorium, Warszawa-Kraków 2002, s. 225.

${ }^{50}$ W 1366 r. Zygfryd zapisał żonie folwark zwany Długim (Lange vorwerk) oraz czynsze w Rakowicach Wielkich i Płóczkach (Lb. I, nr 724). W 1389 r. przekazał jej także dobra w Gaszowie, a jednym z opiekunów oprawy został Dytryk Predel, brat Enedy (Lb. II, nr 605), który był synem Dytryka (Lb. I, nr 484), męża Enedy z możnej rodziny von Rohnau (Lb. I, nr 114).

${ }^{51}$ Lb. I, nr A81; Dytryk miał dobra m.in. w Paszowicach/Poschwitz oraz Kondratowie/ Konradswalde (Lb. I, nr 484, 897; T. J u r e k, Obce rycerstwo, s. 267).

${ }_{52}$ Lb. II, nr 260, 604.

53 Lb. II, nr 606, 787.

54 Występował w testacjach dokumentów wspólnie z Wincentym i Zygfrydem wpisanymi jako rodzeństwo, nigdy jednak nie został nazwany ich bratem (Lb. I, nr 65, 144, 147, 151, $178,244,915)$.

${ }_{55}$ Lb. I, nr 915. Ostrożnie przypuszczać można, że Agnieszka wywodziła się z potężnej rodziny Bolzów. Dwaj jej przedstawiciele - Kleryk i jego syn Henryk - zostali bowiem opiekunami tej oprawy, dwaj inni natomiast byli świadkami tego dokumentu (choć występowali oni wtedy regularnie w testacjach).

56 Fryczko zapisał jej wówczas majątek pod Bolesławcem: w Trzebieniu oraz Nowej Olesznej (Lb. I, nr 88; T. J u r e k, Obce rycerstwo, s. 301).

57 RS nr 4219, 6020.

58 RS nr 6714; RS nr 6948. 
Burgrabia i landwójt lwówecki Zygfryd nie pozostawił męskiego potomstwa. Krótko przed śmiercią, w lutym 1389 r., zapisał wszystko, co posiadał, swoim trzem córkom - Małgorzacie, Enedzie oraz Eufemii. Najważniejsza część spadku - lenno zamkowe i landwójtostwo w Lwówku - przypadła ostatniej z wymienionych sióstr ${ }^{59}$. $\mathrm{Z}$ racji posiadanego majątku Eufemia musiała być świetną partią. Jej pierwszym mężem, odnotowanym w źródłach w 1391 r., został Meinke z piszącej się z zamku Zeiskberg (Cisy) gałęzi rodziny Bolzów ${ }^{60}$. Pochodzący z Turyngii i widoczni na Śląsku od połowy XIII w., Bolzowie należeli do najbardziej wpływowych rodzin w księstwie świdnicko-jaworskim. Ojciec Meinka, ,szlachetny pan” Mikołaj Zeiskberg, był blisko związany z Bolkiem II, a następnie księżną Agnieszką, na której dworze pełnił urząd ochmistrza. Był bardzo bogatym człowiekiem - posiadał lenna zamkowe w Strzegomiu, Świerzawie oraz Wleniu ${ }^{61}$. W 1403 r. Eufemia była już wdową, a w 1411 r. poświadczona jest jako żona Jana Küchmeistra komornika i starosty karniowskiego. Wniosła mu lenno zamkowe i landwójtostwo we Lwówku, a także dobra w Gaszowie, Rakowicach Wielkich i Małych (folwark i altarię), Płóczkach oraz Zbylutowie ${ }^{62}$. Dla Jana mariaż ten mógł być jednak ważny nie tylko ze względu na majątek - sam był zresztą zamożny. W 1412 r. objął urząd starosty świdnicko-jaworskiego ${ }^{63}$, zastrzeżony w zasadzie dla miejscowych terrigenów. Ślub z Eufemią i nabycie dóbr pod Lwówkiem sprawiły, że Jan osiadł w księstwie świdnicko-jaworskim $^{64}$. Mężowie dwóch pozostałych córek Zygfryda Reussendorfa także wywodzili się z liczących się rodzin rycerskich, acz te małżeństwa nie były już tak świetne. Eneda wydana została za Hermana Czirna, syna Franczka i Małgorzaty, piszącego się z Wiesau (Bolków Zdrój pod Bolkowem) ${ }^{65}$. Czirnowie od czasów księcia Bernarda

59 Wesemann I, nr 29; Lb. II, nr 606, 608, 609; B. G. S u t o r i u s, Die Geschichte, s. 79; E. We rn i c ke, Urkundliche Beiträge, s. 485.

${ }^{60}$ Lb. II, nr 950.

${ }^{61}$ Po śmierci Agnieszki Mikołaj należał do najważniejszych osób w otoczeniu starosty królewskiego, od 1396 r. był członkiem jego rady (Die landständische Verfassung von Schweidnitz-Jauer, wyd. G. Croon, Codex diplomaticus Silesiae, t. XXVII, Breslau 1912, s. 181; D. A d a m s k a - H e ś, Urzędnicy nadworni księżnej Agnieszki w latach 1368-1392, Śląski Kwartalnik Historyczny Sobótka 55, 2000, s. 286-87; t a ż, Burgrabiowie, s. 218; T. J u r e k, Obce rycerstwo, s. 204). O tytule „szlachetnego pana” zob. T. J u r e k, Elity, s. 416; M. L. W ó j c i k, Nieznana pieczęć Elżbiety von Parchwitz. Sfragistyczny przyczynek do badań nad życiorysem szlachetnej pani z dynastycznym rodowodem, w: Kobiety i władza w czasach dawnych, Katowice 2015, s. 225.

${ }^{62}$ Lb. III, nr 1502; Wesemann I, nr 32; G. B i e r m a n n, Geschichte der Herzogthümer Troppau und Jägerndorf, Teschen 1874, s. 218; Zemské desky krnovské (1403-1522), wyd. D. Prix, Opava 2008, s. 9.

63 Pozostał na nim jednak krótko, zaledwie do 1414 r. (T. J u re k, Formuła komisyjna w czternastowiecznej kancelarii świdnickiej, Studia Źródłoznawcze 43, 2005, s. 3, przyp. 25).

${ }_{64}$ Podobna praktyka widoczna była także w przypadku poprzednich starostów, również wywodzących się spoza księstwa świdnicko-jaworskiego: Benesza z Choustníka, Jana Kruszyny z Lichtenburka oraz Janka z Chotěmic - D. A d a m s k a, Czeski rycerz na świdnickim dworze. (Przyczynek do kultury politycznej czeskich starostów w księstwie świdnicko-jaworskim), w: Korunní země v dějinách českého státu, Praha 2005, s. 26-28.

65 Jako żona Hermana występowała w dokumentach od 1392 r. (Lb. I, nr 492, II, nr 1056). 
świdnickiego byli wpływową rodziną ${ }^{66}$. Herman był właścicielem licznych dóbr, przede wszystkim w okolicach Świdnicy i Strzegomia, a także Lwówka, gdzie był sąsiadem Reussendorfów ${ }^{67}$. Z dokumentów dotyczących transakcji przeprowadzonych przez Enedę wspólnie z mężem wnioskować można, że dziedziczyła po ojcu dobra w podlwóweckich Skorzynicach, Zbylutowie i Rakowicach Małych ${ }^{68}$. Mężem Małgorzaty natomiast (dowodnie od 1391 r.) był Henryk Wegiste Zedlitz ${ }^{69}$, syn Henczla Wegiste i Judyty, posiadacz dóbr w okolicach Jawora oraz Świdnicy ${ }^{70}$. Zedlitzowie przybyli na Śląsk z Pleißenlandu prawdopodobnie na początku XIV w. Sprawowali liczne urzędy i należeli do najbliższego otoczenia Piastów świdnicko-jaworskich ${ }^{71}$, ale Wegistowie nie należeli jednak wśród nich do najmożniejszych. Mężowie Enedy i Małgorzaty liczyć mogli na zyskanie większej części spadku po Zygfrydzie Reussendorfie, gdyż zgodnie z jego wolą, w przypadku bezpotomnej śmierci Eufemii jej część majątku miała przypaść siostrom ${ }^{72}$. Tak też się stało. Po śmierci Eufemii (nie żyła już w $1418 \mathrm{r}^{73}$ ) lenno zamkowe i landwójtostwo w Lwówku posiadał dożywotnio Jan Küchmeister, ale gdy on zmarł - prawa do nich przeszły na Enedę (Małgorzata najpewniej już nie żyła), ta zaś w $1424 \mathrm{r}$. sprzedała je wraz z dobrami w Rakowicach Kunczkowi z Niemczy (Nimptsch). Z nowym burgrabią mieszczanie lwóweccy toczyli następnie wieloletni spór sądowy dotyczący granicy miasta i lenna zamkowego ${ }^{74}$. W 1424 r. Eneda sprzedała swojemu siostrzeńcowi Mikołajowi Wegiste Długi Folwark (Langenvorwerk), on zaś przekazał jej dożywotnio czynsze w Płóczkach. Jako ich pani dziedziczna została ostatni raz odnotowana w źródłach w sierpniu 1442 r. ${ }^{75}$ Żyła najdłużej spośród córek Zygfryda Reussendorfa.

${ }^{66}$ R. S i k o r ski, Herb rodziny von Czirn w średniowieczu, w: Rody na Śląsku Rusi Czerwonej i w Małopolsce: średniowiecze i czasy nowożytne. Stan badań, metodologia, nowe ustalenia, Rzeszów 2010, s. 176-185; t e n ż e, Czirnowie na średniowiecznym Śląsku wybrane problemy z historii rodu do połowy XIV w., w: Z badań nad historią Śląska i Europy w wiekach średnich, Wrocław 2013, s. 97-121.

${ }^{67}$ W Piotrowicach/Peterwiz (Lb. I, nr 492, II, nr 38, 107), Olszanach/Olsen (Lb. II, 133), Milikowicach/Arnoldsdorf (Lb. II, nr 564, 561, 1332, III, nr 78, 938), Bojanicach/Ludwigsdorf (Lb. II, nr 739), Stanowicach/Stanewitz (Lb. III, nr 962), Bolkowie Zdroju/Wiesau (Lb. II, nr 1398, III, nr 202, 217, 485); w ostatniej miejscowości miał do 1403 r. murowany dwór (Lb. III, nr 1465). Był również współwłaścicielem majątku w Pławnej/Schmottseifen pod Lwówkiem (Lb. II, nr 470).

${ }_{68}$ Lb. II, nr 787, III, nr 1397, 1880.

${ }^{69}$ Lb. II, nr 964, 965, III nr 783; protoplastą tej linii był Jan Wegiste, służacy Bernardowi świdnickiemu i walczący u jego boku pod Mühldorf w Bawarii w $1322 \mathrm{r}$. (W. W a t t e n b a c h, Schlesische Ritter in der Schlacht bei Mühldorf, Zeitschrift des Vereins für Geschichte und Alterthum Schlesiens 3, 1860, s. 199-201; T. Z a w a d z k i, Rodzina von Zedlitz).

70 Chodzi o Jaworów/Jauerau (Lb. I, nr 335), Stanisławów/Wilhelmsdorf (Lb. I, nr A72), Leszczynę/Haselau (Lb. II, nr 1179) i Pomocne/Pombsen (Lb. III, nr A51).

${ }^{71}$ T. Z aw a d z k i, Rodzina von Zedlitz.

${ }^{72}$ Lb. II, nr 608.

${ }^{73}$ Geschichte des Geschlechts von Czettritz und Neuhaus, t. II, opr. H. von Czettritz und Neuhaus, Görlitz 1911, nr A43.

74 Eneda wystąpiła wóczas już jako wdowa po Hermanie Czirnie (Wesseman nr 37; B. G. Sutorius, Die Geschichte, s. 80-82; E. Wernicke, Urkundliche Beiträge, s. 485).

${ }^{75}$ Kleber-Ennen nr 177, 178, 212. 
Ciągłość rodziny zapewniona została przez Wincentego, który pozostawił liczne potomstwo: synów Konrada, Henryka, Jana i Mikołaja ${ }^{76}$ oraz córkę Annę, której mężem został Jone Predel ${ }^{77}$. Majątek Wincentego uległ rozdrobnieniu, a w kolejnych latach był stopniowo uszczuplany przez synów. W 1388 r. przekazali oni wspólnie stryjowi Zygfrydowi 60 grzywien czynszu ze Lwówka, Płóczek, Skorzynic, Zbylutowa, Gaszowa i Olszyny (jako przynależności lwóweckiego lenna zamkowego) ${ }^{78}$. W 1393 r. sprzedali pochodzącemu z Czech Jankowi z Chotěmic zamek Fünfhausen oraz dobra w Mroczkowie (Egelsdorf), Hermannsdorf (Kierżno?) i młyn w Gryfowie. Niska suma tej transakcji (75 grzywien) wynikała zapewne z wcześniejszej już wyprzedaży części tych dóbr ${ }^{79}$. Dalsza aktywność braci, uwieczniona w zapiskach landbucha świdnicko-jaworskiego, dotyczyła często sprzedaży lub zastawów majątku we Lwówku, a przede wszystkim w Płakowicach ${ }^{80}$. Na przełomie XIV i XV w. nastąpiło rozluźnienie więzów Reussendorfów z Lwówkiem, wokół którego głównie koncentrowała się ich wcześniejsza aktywność. Synowie Wincentego podejmowali działalność także w innych, choć niezbyt odległych stronach. Konrad, najstarszy z braci, związany był z Bolesławcem. W 1410 r. nabył od Redernów tamtejsze lenno zamkowe oraz sądownictwo dworskie ${ }^{81}$. Jego żoną została Elżbieta z piszącej się z Lasan (Łażany) pod Strzegomiem gałęzi rodziny Seidlitzów ${ }^{82}$. Ta zamożna rodzina wywodziła się Miśni, a żyła na Śląsku od końca XIII w. ${ }^{83}$ Ojciec Elżbiety, Guncel z Lasan burgrabia strzegomski, był bardzo wpływową postacią na dworze księżnej Agnieszki, która za wierną służbę nadała mu w 1374 r. zamek Radosno (Friedeberg) ${ }^{84}$. Bratem Elżbiety był z kolei Heincze, czeski starosta we Wrocławiu, Namysłowie i Świdnicy ${ }^{85}$. Konrad Reussendorf zmarł w $1418 \mathrm{r}$. i pochowany został w Bolesławicach (Tillendorf) pod Bolesławcem, o czym informuje inskrypcja z płyty jego niezachowanego nagrobka ${ }^{86}$. Jego synem

76 Konrad, Henryk i Jan występują od 1386 (Lb. II, nr 475), Mikołaj od 1388 r. (Lb. II, nr 604); E. W e r n i c k e, Urkundliche Beiträge, s. 485, uznał, że Wincenty miał tylko jednego syn, Zygfryda. W rzeczywistości był to jego młodszy brat. Wernicke znał wprawdzie Henryka, Jana i Konrada, ale nie udało mu się ich powiązać z Wincentym.

77 Dowodnie od 1390 r. (Lb. II, nr 760).

78 Przy tej okazji jedyny raz wymieniony został najmłodszy z braci, Mikołaj (Lb. II, nr 604).

79 Lb. II, nr A11; zob. A. B o g u s z e w i c z, Corona Silesiae, s. 164.

${ }^{80}$ Lb. II, nr 989, 1046, 1113, III, nr 629, 837, 1376, 1377, 1539, 1765, 1890, 1908, 1909, 1912, 1913.

${ }^{81}$ E. We r n i c k e, Chronik, s. 97; t e n ż e, Urkundliche Beiträge, s. 486.

${ }^{82}$ W 1386 r. Konrad przekazał żonie czynsze w Płakowicach, a opiekunami zapisu zostali jej bracia Guncel i Mikołaj (Lb. II, nr 475), synowie Guncela z Lasan i jego żony Zofii (Lb. II, 730, 952).

83 T. J u r e k, Obce rycerstwo, s. 285.

${ }^{84}$ Lb. I, nr 909. Guncel świadczył w ponad 200 dokumentach księżnej (Lb. I, wg indeksu).

85 T. J u r e k, Formuła, s. 3, przyp. 25; E. Wółk i e w i c z, Capitaneus Slesie, s. 221, 225. Nie jest pewne, czy chodzi tu o jednego człowieka, Guncel Lasan miał bowiem aż trzech synów noszących imię Heincze (Lb. II, nr 1161).

${ }^{86}$ Anno dni. MCCCCXVIII - - vorstorben Conrad Ravsendorf - zob. E. We r n i c ke, Bemerkungen, Ergänzungen und Berichtigungen zu neueren für die Geschichte Schlesiens wichtigen Schriften, Zeitschrift des Vereins für Geschichte und Alterthum Schlesiens 19, 1885, s. 409; t e n ż e, Urkundliche Beiträge, s. 486; B. C z e c h o w i c z, Nagrobki późnogotyckie na Śląsku, Wrocław 2003, s. 142. 
był zapewne Konrad Reussendorf zwany Fleck - sędzia dworski w Bolesławcu od $1419 \mathrm{r}^{87}$

Młodsi bracia Konrada - Henryk i Jan - aktywni byli także na Górnych Łużycach ${ }^{88}$. Z rąk króla Wacława IV otrzymali dobra pod Budziszynem. Król przekazał im (oraz Bernardowi Döbschitzowi) w lenno wszystkie swe prawa w Spremberg, Friedersdorf, Taubenheim i Sohland, a także w podwrocławskim Piotrkowie Borowskim (Petrokaw in dem lande zu Breslaw) ${ }^{89}$. Jan pojawiał się w Zgorzelcu ${ }^{90}$, ale świadczył też w wielu dokumentach starostów świdnicko-jaworskich ${ }^{91}$. Piastował również urząd sędziego dworskiego w Bolesławcu ${ }^{92}$. Pisał się z Płakowic i żył jeszcze 1435 r., kiedy świadczył w dokumencie dotyczącym wspomnianego wyżej sporu między miastem Lwówek a burgrabią Kunczkiem o granice lenna zamkowego ${ }^{93}$. Od Jana zapewne wywodzili się Reussendorfowie piszący się później z Płakowic ${ }^{94}$. Potomkami Henryka natomiast - zmarłego między listopadem 1406 a kwietniem $1407 \mathrm{r}^{95}$ - byli z pewnością Reussendorfowie czynni na Łużycach i piszący się ze Spremberg ${ }^{96}$.

Rodzina Reussendorfów wybiła się za sprawą służby książętom i związkom z dworem. Jej pierwszy uchwytny źródłowo przedstawiciel, Henryk, wzbogacił się dzięki łasce Bolka I, a w kolejnym pokoleniu Zygfryd swą działalnością u boku Henryka jaworskiego wyniósł Reussendorfów do rzędu najważniejszych rodzin w okolicy. Awans ułatwiało im - podobnie, jak i innym rodzinom - postępujące

${ }^{87}$ Często od 1410 r. odwiedzający Zgorzelec (Die ältesten Görlitzer Ratsrechnungen bis 1419, wyd. R. Jecht, Codex diplomaticus Lusatiae Superioris, t. III, Görlitz 1905-1910, s. $628,653,659,667,671,684,695,698,703,721,732,755$ [tu pierwszy raz jako sędzia dworski w Bolesławcu], 767, 780, 781; Urząd sędziego dworskiego w Bolesławcu piastowali po Konradzie kolejni Reussendorfowie - zapewne jego potomkowie - Guncel, później zaś bracia Kuncze i Krzysztof (E. We r n i c k e, Urkundliche Beiträge, s. 486; t e n ż e, Chronik, s. 116, 128).

${ }^{88}$ Najwcześniej w Göda pod Budziszynem pojawił się już w 1389 r. Henryk (H. K n o th e, Geschichte, s. 441; Die ältesten Görlitzer Ratsrechnungen, s. 191; W. B o e t t i c h e r, Der Adel, s. 178).

${ }^{89}$ Informuje o tym dokument króla Wacława IV z 1408 r., wydany już po śmierci Henryka Reussendorfa; jego brat Jan sprzedał wówczas wymienione dobra innemu Henrykowi Reussendorfowi, najpewniej synowi zmarłego Henryka (H. K n o th e, Bisher nicht bekannte Oberlausitzer Urkunden, Neues Lausitzsches Magazin 49, 1872, s. 173; t e n ż e, Geschichte, s. 441; W. B o e t t i c h e r, Der Adel, s. 178, który mylił jednak obu Henryków).

90 Die ältesten Görlitzer Ratsrechnungen, s. 549, 659, 664.

${ }_{91}$ Lb. III, nr 232, 318, 406, 409, 469, 503, 553, 711, 931, 993, 881, 813, 1089, 1097, 1303, 1304, 1417, 1455, 1495, 1766, 1880, 1883, 1887, 1888, 1902.

${ }_{92}$ Widoczny na nim od 1413 r. - Wrocław, Archiwum Państwowe, rep 98, nr 50 (47); Die ältesten Görlitzer Ratsrechnungen, s. 679.

93 Wesemann I, nr 40.

94 E. We rn i c k e, Urkundliche Beiträge, s. 487-488.

${ }_{95}$ Lb. III, nr 1766, 1890.

${ }_{96}$ Ze Spremberg pisał się m.in. wspomniany wyżej Henryk Reussendorf (młodszy), znany $\mathrm{z}$ walk przeciwko husytom; w $1421 \mathrm{r}$. wysłał on ludzi do pomocy przy fortyfikowaniu Budziszyna, brał także udział w krucjacie na Czechy i walczył w bitwie pod Aussig/Ústí (Urkunden des Oberlausitzer Hussitenkrieges und der gleichzeitigen die Sechslande angehenden Fehden. t. I, wyd. R. Jecht, Codex diplomaticus Lusatiae Superioris, t. II, Görlitz 1896-1899, s. 42; H. K n o th e, Die Besitzungen, s. 193; t e n ż e, Geschichte, s. 441; W. B o e t t i c h e r, Der Adel, s. 178-179). 
rozdrobnienie księstw śląskich, w ramach których coraz większe znaczenie ekonomiczne, ale i polityczne, zyskiwali mieszczanie głównych miast. W czasach księcia Bolka II, którego dwór oferował jeszcze spore możliwości kariery, Wincenty oraz Zygfryd Reussendorf, synowie Zygfryda, nie szukali jednak z nim bliższych związków. Wskazuje to chyba na okrzepłą już pozycję majątkową i społeczną97. Rosnące znaczenie rodziny manifestowało przyjmowanie typowych oznak awansu społecznego, przede wszystkim sprawowanie godności duchownych i świeckich. Już Jan Reussendorf (syn wspomnianego Henryka) uzyskał prebendy w kapitułach kolegiackich u św. Krzyża we Wrocławiu i w Legnicy, acz na Śląsku kanonie nie były zastrzeżone dla synów szlacheckich. Jego brat Zygfryd piastował funkcję sędziego dworskiego w Lwówku. Aktywni byli także synowie tego ostatniego - Wincenty (burgrabia gryfowski i landwójt złotoryjski) oraz Zygfryd (burgrabia i landwójt lwówecki) - a także przedstawiciele kolejnych pokoleń, dziedziczący w XV w. funkcję sędziego dworskiego w Bolesławcu. Nabywając liczne majątki ziemskie, Reussendorfowie wyszli poza stan mieszczański. Już synowie wspomnianego protoplasty Henryka nie byli określani mieszczanami. Za sprawą praw i obowiązków wynikających z posiadania dóbr lennych stylem życia upodabniać zaczęli się do rycerstwa. Na Śląsku w XIV w. rycerstwo nie było grupą zamkniętą, ale kształtowało się jako warstwa zobowiązanych do służby konnej posiadaczy lenn. O wejściu Reussendorfów w szeregi rycerstwa świadczy przyjęcie przez nich najważniejszych atrybutów właściwych tej warstwie. W połowie XIV w. bracia Wincenty i Zygfryd nosili pas rycerski. Reussendorfowie przyjęli także herb. Najstarsze jego poświadczenie przynosi pieczęć Zygfryda z 1335 r. przedstawiająca ustawioną prosto tarczę, na której widnieje popiersie Murzyna ${ }^{98}$. Ten sam motyw znamy z pieczęci jego wnuków Konrada, Henryka oraz Jana $(1387,1393)^{99}$. Na pieczęci ostatniego z braci z 1415 r. widnieje tarcza pochylona (znów z popiersiem Murzyna) ${ }^{100}$, co powtarza się na pieczęci Kuncza z 1478 r. ${ }^{101}$ $\mathrm{W}$ czasach nowożytnych herb Reussendorfów przedstawiał tarczę dzieloną w pas - pole górne było czerwone, dolne zaś skwadrowane, przy czym powstałe $\mathrm{w}$ ten sposób pola 1 i 4 były czarne, a 2 i 3 -złote; klejnot wyobrażał głowę Murzyna ${ }^{102}$. Podobnego klejnotu używała spowinowacona z Reussendorfami rodzina Czirnów, również osiadła w księstwie świdnicko-jaworskim. Głowa Murzyna nawiązywała do francuskiego poematu opowiadającego o pojedynku szachowym stoczonym w Grenadzie przez rycerza Huona z Bordeaux z córką saraceńskiego admirała

97 Tego typu nastawienie było wówczas częste na Śląsku (T. J u r e k, Rotacja elity dworskiej na Śląsku w XII-XIV w., w: Genealogia - władza i społeczeństwo w Polsce średniowiecznej, Toruń 1999, s. 19-20; t e n ż e, Elity, s. 413).

98 Praha, Národní archiv, Archiv českého velkopřevorství Maltského řádu, nr 351.

99 Tamże, nr 356, 481.

100 Tamże, nr 482. Za informacje o przechowywanych w Pradze pieczęciach Reussendorfów dziękuję Panu dr. Markowi L. Wójcikowi z Instytutu Historycznego Uniwersytetu Wrocławskiego.

101 Wrocław, Archiwum Państwowe, rep. 9, nr 223 (387).

102 N. H e n e 1, Silesiographia renovata, t. II, Wratislaviae-Lpisiae 1704, s. 718; J. S i n a p i u s, Schlesische Curiositäten, s. 748 (gdzie także inna wersja herbu: pole 1 i 4 złote, 2 i 3 czerwone); Schlesisches Wappenbuch von Crispin und Johann Scharffenberg, opr. H. Mosch, Neustadt and der Aisch 1984, tab. 183. 
Yvarina ${ }^{103}$. Obecność tego motywu u wspomnianych rodzin śląskich (choć jego recepcji nie potrafimy wydatować) zdaje się świadczyć o znajomości tego popularnego wątku poezji dworskiej. Ze wspomnianymi godnościami burgrabiowskimi wiązała się kontrola i posiadanie książęcych pierwotnie zamków. Stanowiły one centra zarządu, wokół których nowi posiadacze budowali swe zwarte kompleksy majątkowe, ale przede wszystkim pełniły funkcje reprezentacyjne, zapewniając odpowiedni prestiż $^{104}$. Dysponowanie zamkami stawało się w późnym średniowieczu ważnym wyznacznikiem wysokiej pozycji społecznej. Wejście Reussendorfowie do elitarnego grona posiadaczy zamków nastąpiło wraz z nabyciem zamku Gryf przez Zygfryda (1354). Do jego synów Wincentego i Zygfryda należały również zamki we Lwówku i Fünfhausen, a w następnym pokoleniu, za sprawą Konrada, w rękach rodziny znalazł się też zamek w Bolesławcu (1410). To z grona ich posiadaczy wywodziła się wąska grupa „szlachetnych panów” ${ }^{105}$. Reussendorfowie nie byli wprawdzie tak określani w źródłach, a o ich przynależności do śląskiej elity wpływów świadczą majątki z zamkami oraz koligacje z najbardziej liczącymi się ówcześnie rodzinami, w tym ,szlachetnymi panami” Bolzami z Zeiskberg, Küchmeistrami czy Seidlitzami z Lasan. Manifestacja osiągniętej pozycji społecznej znajdowała swój wyraz w kościelnych fundacjach mających na celu zabezpieczenie i utrwalenie pamięci o nich. Reussendorfowie ufundowali kaplicę rodzinną w Bolesławicach. Jako pierwszy spoczął w niej w 1418 r. Konrad Reussendorf. Pod koniec XV w. poświadczone mamy także istnienie należącej do naszej rodziny kaplicy w kościele franciszkanów w Lwówku ${ }^{106}$. Szczyt kariery Reussendorfów przypadł na okres aktywności Wincentego i jego brata Zygfryda w drugiej połowie XIV w. Brak męskich potomków i wygaśnięcie linii drugiego z nich doprowadziły do utraty dominującego znaczenia rodziny w samym Lwówku. Rozrodzeni potomkowie Wincentego dzielili natomiast i rozdrabniali odziedziczony majątek. Dali początek nowym gałęziom rodziny związanym już nie tylko z Lwówkiem, lecz także z Łużycami oraz Bolesławcem, w którym odgrywali dużą rolę do w XV w.

\section{BIBLIOGRAFIA}

Adamska D., Czeski rycerz na świdnickim dworze. (Przyczynek do kultury politycznej czeskich starostów w księstwie świdnicko-jaworskim), w: Korunní země v dějinách českého státu, Praha 2005.

Adamska D., Fundacje dewocyjne rycerstwa księstwa świdnicko-jaworskiego w średniowieczu, Poznań-Wrocław 2005.

Adamska-Heś D., Burgrabiowie księstwa świdnicko-jaworskiego w drugiej połowie XIV w., Śląski Kwartalnik Historyczny Sobótka 56, 2001.

Adamska-Heś D., Personel kancelaryjny księżnej Agnieszki świdnicko-jaworskiej w latach 1368-1392, Śląski Kwartalnik Historyczny Sobótka 55, 2000.

103 R. S i k orski, Herb, s. 179-181; zob. J. Wi e s i ołow sk i, Hołub z Bordeaux herbu Wczele, Rocznik Polskiego Towarzystwa Heraldycznego, seria nowa 1, 1993, s. 13-23.

104 T. J u r e k, Elity, s. 414-416.

105 Tamże, s. 416; M. L. W ó j c i k, Nieznana pieczęć, s. 225.

106 W 1482 r. Guncel Reussendorf przekazał franciszkanom folwark w Płakowicach, w zamian za co zakonnicy mieli w owej kaplicy odprawiać msze w intencji zbawienia duszy jego ojca (D. A d a m ska, Fundacje, s. 91). 
Adamska-Heś D., Urzędnicy nadworni księżnej Agnieszki w latach 1368-1392, Śląski Kwartalnik Historyczny Sobótka 55, 2000.

Bergmann J. G., Beschreibung und Geschichte der alten Burgfeste Greiffenstein, Bunzlau 1832.

Biermann G., Geschichte der Herzogthümer Troppau und Jägerndorf, Teschen 1874.

Boetticher W., Der Adel des Görlitzer Weichbildes um die Wende des 14. und 15. Jahrhunderts, Görlitz 1927.

Bogucki A., Nazwy rycerstwa w Regestach śląskich, Śląski Kwartalnik Historyczny Sobótka 46, 1991.

Bogucki A., Termin miles w regestach śląskich XIII i XIV, w: Społeczeństwo Polski średniowiecznej, t. I, Warszawa 1981.

Boguszewicz A., Corona Silesiae. Zamki Piastów fürstenberskich na południowym pograniczu księstwa jaworskiego, świdnickiego i ziębickiego do połowy XIV wieku. Wrocław 2010.

Cetwiński M., Rycerstwo śląskie do końca XIII w., cz. I: Pochodzenie - gospodarka - polityka, Wrocław 1980.

Czechowicz B., Nagrobki późnogotyckie na Śląsku, Wrocław 2003.

Geschichte des Geschlechts von Czettritz und Neuhaus, t. II, opr. H. von Czettritz und Neuhaus, Görlitz 1911.

Graniczny J., Rycerstwo księstw jaworskiego i świdnickiego w latach 1274-1346, w: Człowiek i środowisko w Sudetach, Wrocław 2000.

Grodecki R., Dzieje polityczne Śląska do roku 1290, w: Historia Śląska od najdawniejszych czasów do roku 1400, t. I, Kraków 1933.

Irgang W., Das spätmittelalterliche Stadtbuch von Löwenberg in Schlesien, Zeitschrift für Ostforschung 45, 1996.

Jujeczka S., Duchowni średniowiecznej Legnicy. Studium prozopograficzne nad klerem diecezjalnym, Legnica 2006.

Jurek T., Elity Śląska w późnym średniowieczu, w: Kolory i struktury średniowiecza, Warszawa 2004.

Jurek T., Formuła komisyjna w czternastowiecznej kancelarii świdnickiej, Studia Źródłoznawcze 43, 2005.

Jurek T., In sede viduali. Nad itinerarium księżnej świdnickiej Agnieszki z lat 1385-1392, w: Europa Środkowa i Wschodnia w polityce Piastów, Torun 1997.

Jurek T., Najdawniejsze wywody szlachectwa na Śląsku, Śląski Kwartalnik Historyczny Sobótka 49, 1994.

Jurek T., Obce rycerstwo na Śląsku do połowy XIV wieku, Poznań 1996.

Jurek T., Rotacja elity dworskiej na Śląsku w XII-XIV w., w: Genealogia - władza i społeczeństwo w Polsce średniowiecznej, Toruń 1999.

Jurek T., Vom Rittertum zum Adel. Zur Herausbildung des Adelsstandes im mittelalterlichen Schlesien, w: Adel in Schlesien, t. I: Herrschaft - Kultur - Selbstdarstellung, München 2010.

Karłowska-Kamzowa A., Fundacje artystyczne księcia Ludwika I brzeskiego, Opole-Wrocław 1970.

Kleber P., Löwenberg unter den Piasten, t. I, Löwenberg 1914.

Knothe H., Bisher nicht bekannte Oberlausitzer Urkunden, Neues Lausitzsches Magazin 49, 1872.

Knothe H., Die Besitzungen des Bisthums Meißen in der Oberlausitz, Archiv für die sächsische Geschichte 6, 1867.

Knothe H., Die Huldigung des Görlitzer Rathes an Herzog Heinrich von Jauer 1322, Zeitschrift des Vereins für Geschichte und Alterthum Schlesiens 8, 1868.

Knothe H., Geschichte des oberlausitzer Adels und seiner Güter vom XIII. bis gegen Ende des XVI. Jahrhunderts, Leipzig 1879.

Kokocińska M., Kancelaria Bolka I księcia jaworsko-świdnickiego, Szkice Legnickie 21, 2000.

Kuchendorf C., Das Breslauer Kreuzstift in seiner persönlichen Zusammensetzung von der Gründung (1288) bis 1456, Breslau 1937. 
Maleczyński K., Śląsk w okresie od poł. XIII w. do poł. XIV w., w: Historia Śląska, t. I, cz. 1, Wrocław 1960.

Nowakowa J., Rozmieszczenie komór celnych i przebieg dróg handlowych na Śląsku do końca XIV w., Wrocław 1951.

Prokop K. R., Miasta księstwa legnickiego w polityce ekonomicznej książąt Bolesława III i Wacława I (1306-1364), cz. 2, Szkice Legnickie 26, 2005.

Rössler R., Urkunden Herzog Ludwig I. von Brieg, cz. 1, Zeitschrift des Vereins für Geschichte und Alterthum Schlesiens 6, 1884.

Sikorski R., Czirnowie na średniowiecznym Śląsku - wybrane problemy z historii rodu do połowy XIV w., w: Z badań nad historią Śląska i Europy w wiekach średnich, Wrocław 2013.

Sikorski R., Herb rodziny von Czirn w średniowieczu, w: Rody na Śląsku Rusi Czerwonej i w Małopolsce: średniowiecze i czasy nowożytne. Stan badań, metodologia, nowe ustalenia, Rzeszów 2010.

Sinapius J., Schlesische Curiositäten, t. I-II, Leipzig-Breslau 1720-1728.

Sutorius B. G., Die Geschichte von Löwenberg aus Urkunden und Handschriften gesammelt, t. I, Bunzlau 1784.

Szafrański F., Ludwik II brzesko-legnicki. Feudał śląski z doby późnego średniowiecza, Wrocław 1972.

Wattenbach W., Schlesische Ritter in der Schlacht bei Mühldorf, Zeitschrift des Vereins für Geschichte und Alterthum Schlesiens 3, 1860.

Wereszczyński W., Fünfhausen - zaginione lenno zamkowe u podnórza Gór Izerskich, Rocznik Jeleniogórski 36, 2004.

Wernicke E., Bemerkungen, Ergänzungen und Berichtigungen zu neueren für die Geschichte Schlesiens wichtigen Schriften, Zeitschrift des Vereins für Geschichte und Alterthum Schlesiens 19, 1885.

Wernicke E., Chronik der Stadt Bunzlau von den ältesten Zeiten bis zur Gegenwart, Bunzlau 1884.

Wernicke E., Urkundliche Beiträge zur Geschichte der Adelsfamilien in den ehemals vereinigten Kreisen Bunzlau-Löwenberg, Vierteljahrsschrift für Heraldik, Sphragistik und Genealogie $14,1886$.

Wiesiołowski J., Hołub z Bordeaux herbu Wczele, Rocznik Polskiego Towarzystwa Heraldycznego, seria nowa 1, 1993.

Wójcik M. L., Nieznana pieczęć Elżbiety von Parchwitz. Sfragistyczny przyczynek do badań nad życiorysem szlachetnej pani z dynastycznym rodowodem, w: Kobiety i władza w czasach dawnych, Katowice 2015.

Wółkiewicz E., Capitaneus Slesie. Królewscy namiestnicy księstwa wrocławaskiego i Śląska w XIV i XV wieku, w: Monarchia w średniowieczu - władza nad ludźmi, władza nad terytorium, Warszawa-Kraków 2002.

Zawadzki T., Rodzina von Zedlitz w księstwach świdnicko-jaworskim oraz legnickim w XIV wieku, Sredniowiecze Polskie i Powszechne 9 (13), 2017.

\section{Burghers, knights, burggraves}

The career of the Silesian family von Reussendorf in pre-Hussite times

\section{Summary}

The Reussendorfs were a burgher family from Lwówek (Löwenberg), appearing in sources from the end of the $13^{\text {th }}$ century, whose history forms a good example of social advance of Sielsian middle class in medieval times. They rose in importance thanks to their service at the courts of Bolko I the Strict and Henry of Jawor (Jauer), and in the $14^{\text {th }}$ century belonged to the 
most influential and the richest families in the Duchy of Świdnica-Jawor (Schweidnitz-Jauer). As a consequence of purchasing land estates as fiefs and the duty of military horse service connected to it, the Reussendorfs entered the ranks of knighthood, accepting the basic attributes of that class - the knight's belt and coat-of-arms. Their high position is confirmed by numerous offices held by them, various castle fiefs possessed, as well as excellent marital colligations with the most powerful knightly families of the period. The peak of the Reussendorfs' career occurred in the second half of the 14th century. Their importance diminished from the end of that century because of the extinction of one branch of the family and a large number of descendants (which caused fragmentation of the estate) in the other branch. Members of the family, earlier connected mainly to the region of Lwówek, became active also in the nearby regions of Lusatia and in Bolesławiec (Bunzlau). 


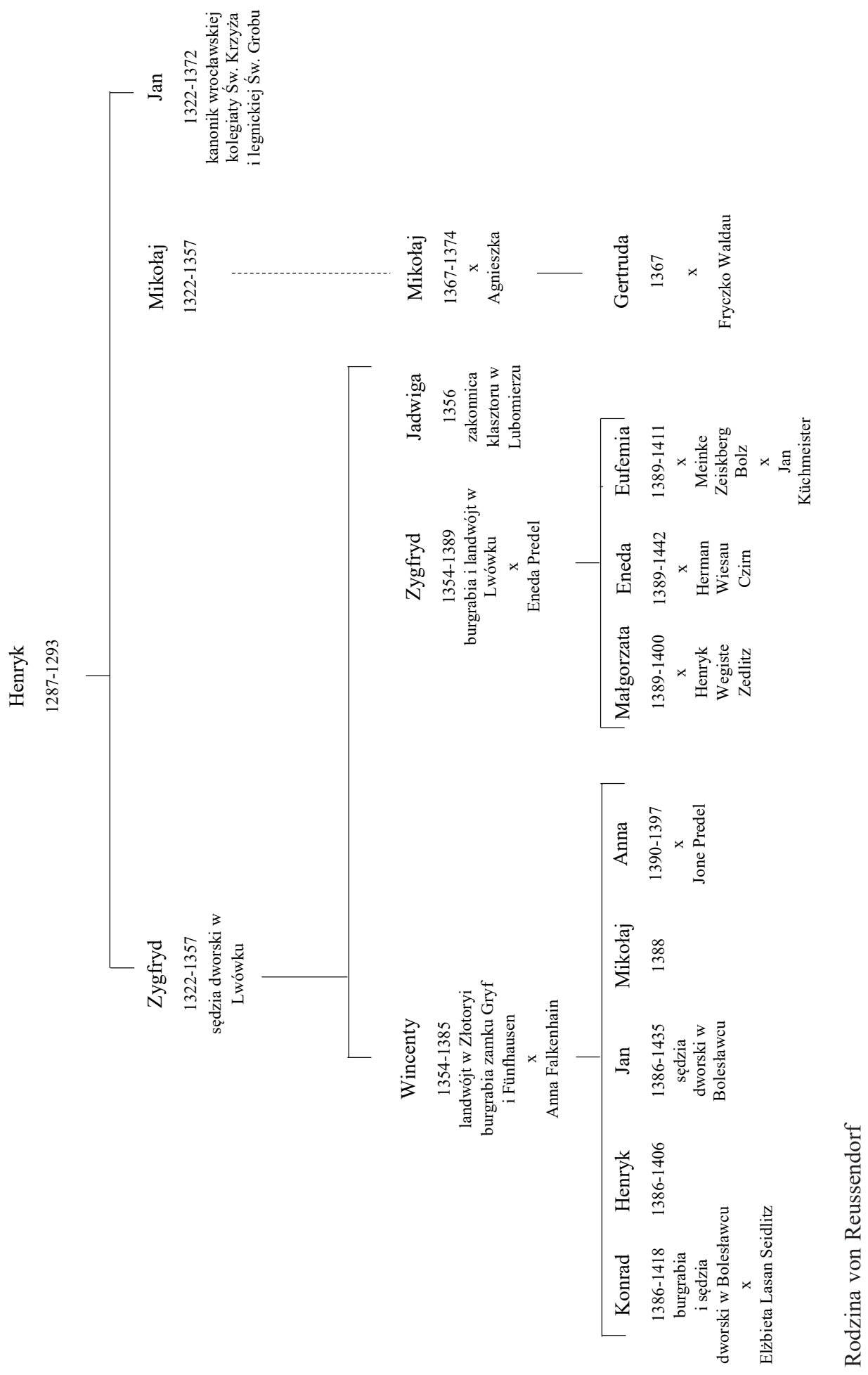

